\title{
Calcite production by the calcifying green alga Phacotus lenticularis
}

\author{
Sebastian LENZ,${ }^{*}{ }^{*}$ Uta GRUENERT, ${ }^{2}$ Juergen GEIST, ${ }^{1}$ Michael STIEFEL,${ }^{3}$ Maren LENTZ, ${ }^{4}$ Uta RAEDER ${ }^{1}$
}

${ }^{1}$ Department of Life Sciences Weihenstephan, Aquatic Systems Biology Unit, Limnological Research Station Iffeldorf, Technical University of Munich, Germany; ${ }^{2}$ Institute of Evolution and Ecology, Plant Evolutionary Ecology, University of Tübingen, Germany; ${ }^{3}$ EMPA, Swiss Federal Laboratories for Materials Science and Technology, Dübendorf, Switzerland; ${ }^{4}$ IGB, Leibniz-Institute of Freshwater Ecology and Inland Fisheries, Stechlin, Germany

*Corresponding author: s.lenz@tum.de

\begin{abstract}
The importance of carbonate precipitation by phytoplankton in fresh water lakes has not been sufficiently considered in global carbon cycles and climate change scenarios. The objective of this study was to determine the influence of the calcifying bivalved phytoflagellate Phacotus lenticularis (Ehrenberg) Deising 1866 on the total calcite precipitation in five European hard-water lakes. For this purpose, an accurate mass determination of single Phacotus lenticularis shells was required. We developed a novel methodological approach to precisely determine the volume and mass of the calcified shells. Focused ion beam (FIB) techniques were employed to investigate internal structural features. Thin layer cross-sections of the shell profiles were reproduced and perforation as well as the crystalline structure of the calcite plates were monitored. 3D-shell models were computed by $360^{\circ}$ rotation of the shell cross-sections using a CAD 3D imaging software to calculate precise volumes and estimate realistic masses. In contrast to previous estimates, we determined a 2.8 -fold higher shell mass of $0.86 \mathrm{ng} \mathrm{CaCO}_{3}(\mathrm{SD}=0.18)$ for the highly massive shells at a mean volume per individual of $334.1 \mu \mathrm{m}^{3}(\mathrm{SD}=70)$. An initial shell porosity of less than $5 \%$ was derived from thin layer cross-

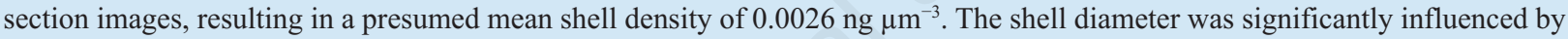
the lake's origin. The shells from each lake displayed substantial variations in diameter and shape. The pores in the shells showed two variations. Wider pore canals penetrated the whole shell wall, whereas small, elongated pores were located along the interspaces between calcite crystals with tabular habit. The approximate average dimensions of these calcite plates were $1.0 \times 1.6 \times 0.2 \mu \mathrm{m}$. The mean lateral wall thickness at the rim and centre of the shell were $1.98 \mu \mathrm{m}(\mathrm{SD}=0.42)$ and $0.79 \mu \mathrm{m}(\mathrm{SD}=0.17)$, respectively. The average carbonate precipitation by Phacotus lenticularis in relation to the total epilimnetic suspended calcite precipitation was $6 \%$ in the oligotrophic lake Großer Ostersee (Bavaria, Germany). During the growing season, Phacotus lenticularis contributed up to $21 \%$ of the particulate calcium carbonate in the epilimnion. These findings suggest that Phacotus lenticularis should be considered in the assessment of hard-water lake carbon cycling.
\end{abstract}

Key words: Autochthonous calcite precipitation; calcite shells, hard-water lake; mass determination; focused ion beam.

Received: July 2017. Accepted: December 2017.

\section{INTRODUCTION}

The role of inland aquatic systems in C-cycling is poorly understood. In addition to the terrestrial C-input into aquatic systems (Cole et al., 2007), there can also be substantial C-fixation by primary producers within aquatic systems. Carbonate precipitation induced by planktonic algae is a process that has been widely investigated in marine environments. However, it also occurs in freshwater ecosystems, but there is less information available about its importance in these ecosystems. The calcifying freshwater flagellate Phacotus lenticularis (Ehrenberg) Deising 1866 (Chlorophyceae, Chlamydomonadales, Phacotaceae) is abundant in temperate hard-water lakes worldwide. These unicellular green algae have been reported to incorporate remarkable amounts of $\mathrm{CaCO}_{3}$ in their shells (Giering et al., 1990; Koschel et al., 1987; Koschel and Raidt, 1988; Pocratsky,
1982; Sieminska, 1952; Sladecek et al., 1958; Steinberg and Klee, 1983), consisting of $98 \%-99 \%$ pure $\mathrm{CaCO}_{3}$ (Schlegel et al., 1998). It is assumed that it temporally contributes up to $100 \%$ of the autochthonous calcite precipitation during mass development (Koschel and Raidt, 1988). Consequently this species brings about high autochthonous $\mathrm{CaCO}_{3}$ inputs in these lakes and plays a definite role in limnic carbonate sedimentation as a sediment contributor (Koschel et al., 1987; Müller and Oti, 1981).

Previous works have described the external and structural features of Phacotus shells (often named lorica) in great detail. The mineralised external housing has a simple radially symmetric morphology and is formed by rhombohedral calcite crystals that are arranged in several rings around a central rotational axis (Kamptner, 1950; Koschel and Raidt, 1988). However, several important aspects remain controversial. For instance, it is unknown 
if the interspaces between the rhombohedral crystals are filled with calcite or remain empty. Also, internal orientation and extensions of the crystals have not been described so far. Moreover, there have been no explicit measurements of their porosity. Phacotus shells are likely to vary in morphotype and surface porosity over time and location (Schlegel et al., 2000). Variations in shell diameter between 6-17 $\mu \mathrm{m}$ have been reported (Giering et al., 1990; Koschel and Raidt, 1988; Pocratsky, 1982; Schlegel et al., 2000; Steinberg and Klee, 1983). However, none of these works systematically determined the precise amount of calcite within a shell. Furthermore, there has been no explicit assessment of the individual variations of the general dimensions, nor calculations of the volume of Phacotus shells from different lakes.

A single provisional estimation based on conductometry has been reported by Koschel et al. (1987), which suggested a shell mass of $0.3 \mathrm{ng} \mathrm{CaCO}_{3}$ per individual shell. This result was derived from a particularly suitable Phacotus mass development in which the shells accounted for $100 \%$ of autochthonous calcite. To the best of our knowledge, this value has not yet been verified, and a repetition of the measurement seems difficult because i) it is exceptionally rare that mass developments account for $100 \%$ of autochthonous calcite precipitation, and ii) in all other cases mass determination of exclusively Phacotus shells is generally impeded by co-precipitated calcite crystals.

In our study, we built the basis for a quantitative determination of the potential role of Phacotus lenticularis in carbonate precipitation in lakes. Our methodical approach revealed new insights on the internal ultrastructure of the Phacotus shell and enabled us to verify and estimate the porosity of the material. We measured the relevant external shell parameters, calculated the precise shell volumes, and estimated the realistic shell masses of 24 individual shells from five different lakes. We investigated if there is a variation of the Phacotus diameter in lakes with different trophic states and during the growing season. Finally, we determined the amount of Phacotus calcite in relation to the total calcite precipitation in the epilimnetic layer of the oligotrophic lake Großer Ostersee (Bavaria, Germany) and addressed the question of whether Phacotus lenticularis significantly affects the $\mathrm{CaCO}_{3}$ budget of this lake.

\section{METHODS}

\section{Study sites}

Phacotus shells for mass determination were derived from five lakes in southern Bavaria, Germany: lake Abtsdorfer See (ABS), lake Altmühlsee (ALT), lake Großer Ostersee (GOS), lake Hopfensee (HOP) and lake Igelsbachsee (IGS). The lakes differed in surface area, maximum depth, and trophic state (Tab. 1), but held significant Phacotus lenticularis occurrences with cell densities of more than $1 \times 10^{5}$ individuals per litre (ind. $\mathrm{L}^{-1}$ ). Intensive investigations on suspended carbonate and Phacotus population dynamics in lake Großer Ostersee were conducted. Lake Großer Ostersee was fed by alkaline groundwater with a catchment area comprising $35 \mathrm{~km}^{2}$ (Gruenert and Raeder, 2014).

\section{Sampling}

Samples for volumetric shell measurements were taken in June and August 2016 from the epilimnetic layer (0-7 $\mathrm{m}$ depth) at the deepest point of each lake. Integrated water samples were taken with a PE sampling tube $(7 \mathrm{~m}$ length and $4.5 \mathrm{~cm}$ diameter) with a $2.5 \mathrm{~kg}$ weight at the bottom end. The tube was slowly let down vertically into the water. Its content was filled into a $6 \mathrm{~L}$ canister and homogenised by shaking prior to further processing. Samples for the measurements of the Phacotus shell abundance and total epilimnetic particulate calcite were

Tab. 1. Characteristics of selected hard water lakes and geographic sampling positions in Bavaria, Germany.

\begin{tabular}{|c|c|c|c|c|c|}
\hline & Gr. Ostersee & Abtsdorfersee & Igelsbachsee & Hopfensee & Altmühlsee \\
\hline Trophic state & Oligotrophic & Mesotrophic & Mesotrophic & Eutrophic & Hypertrophic \\
\hline Circulation type & Dimictic & Dimictic & Polymictic & Dimictic & Polymictic \\
\hline Surface area (ha) & 118 & 78 & 72 & 186 & 450 \\
\hline Max. depth (m) & 29.7 & 20.0 & 11.5 & 10.4 & 2.2 \\
\hline \multirow{2}{*}{ Coordinates (WGS 84) } & $47^{\circ} 47^{\prime} 25.2 ”$ & $47^{\circ} 54^{\prime} 35.4 ’$ & $49^{\circ} 08^{\prime} 45.3 \prime$ & 47³6’06.1”, & $49^{\circ} 08^{\prime} 35.8^{\prime \prime}$ \\
\hline & $011^{\circ} 18^{\prime} 06.5^{\prime \prime}$ & $012^{\circ} 54^{\prime} 22.4^{\prime \prime}$ & $010^{\circ} 54^{\prime} 13.3^{\prime \prime}$ & $010^{\circ} 40^{\prime} 46.6^{\prime \prime}$ & $010^{\circ} 43^{\prime} 34.4 "$ \\
\hline Water temp. $\left({ }^{\circ} \mathrm{C}\right)$ & $17.4(4.7)$ & $15.5(5.2)$ & $20.9(2.7)$ & $17.3(2.8)$ & $22.1(1.6)$ \\
\hline $\mathrm{pH}$ value & $8.2(0.2)$ & $7.9(0.4)$ & $8.6(0.5)$ & $8.2(0.4)$ & $9.0(0.3)$ \\
\hline $\mathrm{Ca}^{2+}$ conc. $\left(\mathrm{mg} \mathrm{L}^{-1}\right)$ & 69.2 & 78.2 & 37.6 & 69.3 & 47.1 \\
\hline $\mathrm{TP}\left(\mu \mathrm{g} \mathrm{L}^{-1}\right)$ & $>8.2$ & $>17.4$ & $>25^{*}$ & $>35^{* *}$ & $>200^{*}$ \\
\hline Secci depth (m) & $3.3(0.6)$ & $1.1(0.2)$ & $3.0(0.6)$ & $1.1(0.3)$ & $0.5(0.2)$ \\
\hline
\end{tabular}

Physical, chemical average values of the surface layer (0-7 m) during June till August 2016; TP data from Bavarian Environmental Agency; *2014;

**2013; $\mathrm{Ca}^{2+}$ concentration from last sampling in August; SD in brackets. 
taken between 0-5 $\mathrm{m}$ depth to ensure comparability with previous works. Sampling was carried out weekly at the deepest point of each lake during the Phacotus growing season from June to October 2015. These samples were taken with a standard Ruttner water sampler and integrated by mixing aliquots inside a measuring cup. Water temperature, $\mathrm{pH}$ depth profiles and concentrations of $\mathrm{Ca}^{2+}$ in solution were measured according to Gruenert and Raeder (2014).

\section{Infrared gas analysis for carbonate determination}

Particulate $\mathrm{CaCO}_{3}$ concentrations were measured by infrared (IR) $\mathrm{CO}_{2}$ analysis. We used a revised method with a modified measurement setup (Fig. 1) based on the former conductometric $\mathrm{CO}_{2}$ analysis reported by Proft $(1983,1984)$. This enabled a more precise determination of the suspended calcite in lake water samples.

Each lake water sample $(200 \mathrm{~mL})$ was filtrated through $0.45 \mu \mathrm{m}$ cellulose-nitrate filters. The filters were oven dried overnight at $50^{\circ} \mathrm{C}$ and stored in a desiccator before introducing them with tweezers into a reaction vessel containing $10 \% \mathrm{HCl}$ solution. A carrier gas was streamed through the reaction vessel and absorbed the emerging $\mathrm{CO}_{2}$ released by carbonate dissolution. Prior to $\mathrm{CO}_{2}$ gas analysis with a Saxon Junkalor GmbH (Dessau, Germany) Infralyt 50 gas analyser, the carrier gas was passed through $\mathrm{Cu}$ flakes to remove any $\mathrm{HCl}$ and dried by passing it through granulated $\mathrm{CaCl}_{2}$. The carrier gas was air from the lab, which was pumped with a constant gas flow of $33 \mathrm{~mL} \mathrm{~s}^{-1}$ through $\mathrm{NaOH}$ pellets before use to remove the atmospheric $\mathrm{CO}_{2}$.

The system was calibrated for a measuring range between $0.005-0.05$ [mg C L L $\mathrm{mg}^{-1}$ with a IC-standard solution (containing $\mathrm{NaHCO}_{3}$ and $\mathrm{Na}_{2} \mathrm{CO}_{3}$ ). The Infralyt 50 measured the $\mathrm{CO}_{2}$ content displayed as ppm $\mathrm{CO}_{2}$ and the LC-Net-Box transformed the analogue signal to a digital signal for processing with the Jasco (Easton, Maryland, USA) Borwin 1.5 software. The output dimension was given as carbon concentration $\mathrm{c}_{\mathrm{C}}[\mathrm{mg} \mathrm{C}$ $\left.\mathrm{L}^{-1}\right]$. Before each measurement, the background $\mathrm{CO}_{2}(\leq 1$ $\mathrm{ppm}$ ) was set to zero. Measurement time for one sample was $180 \mathrm{~s}$. The $10 \% \mathrm{HCl}$ solution in the reaction vessel was renewed after the measurement of 10 samples. The conversion of $\mathrm{c}_{\mathrm{C}}$ to $\mathrm{c}_{\mathrm{CaCO} 3}$ concentration was calculated by multiplication of $\mathrm{c}_{\mathrm{C}}$ with the ratio of the molecular weights $\mathrm{M}_{\mathrm{CaCO} 3} 100.09 \mathrm{~g} \mathrm{~mol}^{-1}$ and $\mathrm{M}_{\mathrm{C}} 12.01 \mathrm{~g} \mathrm{~mol}^{-1}$ according to equation 1 . After every 20 measurements, a

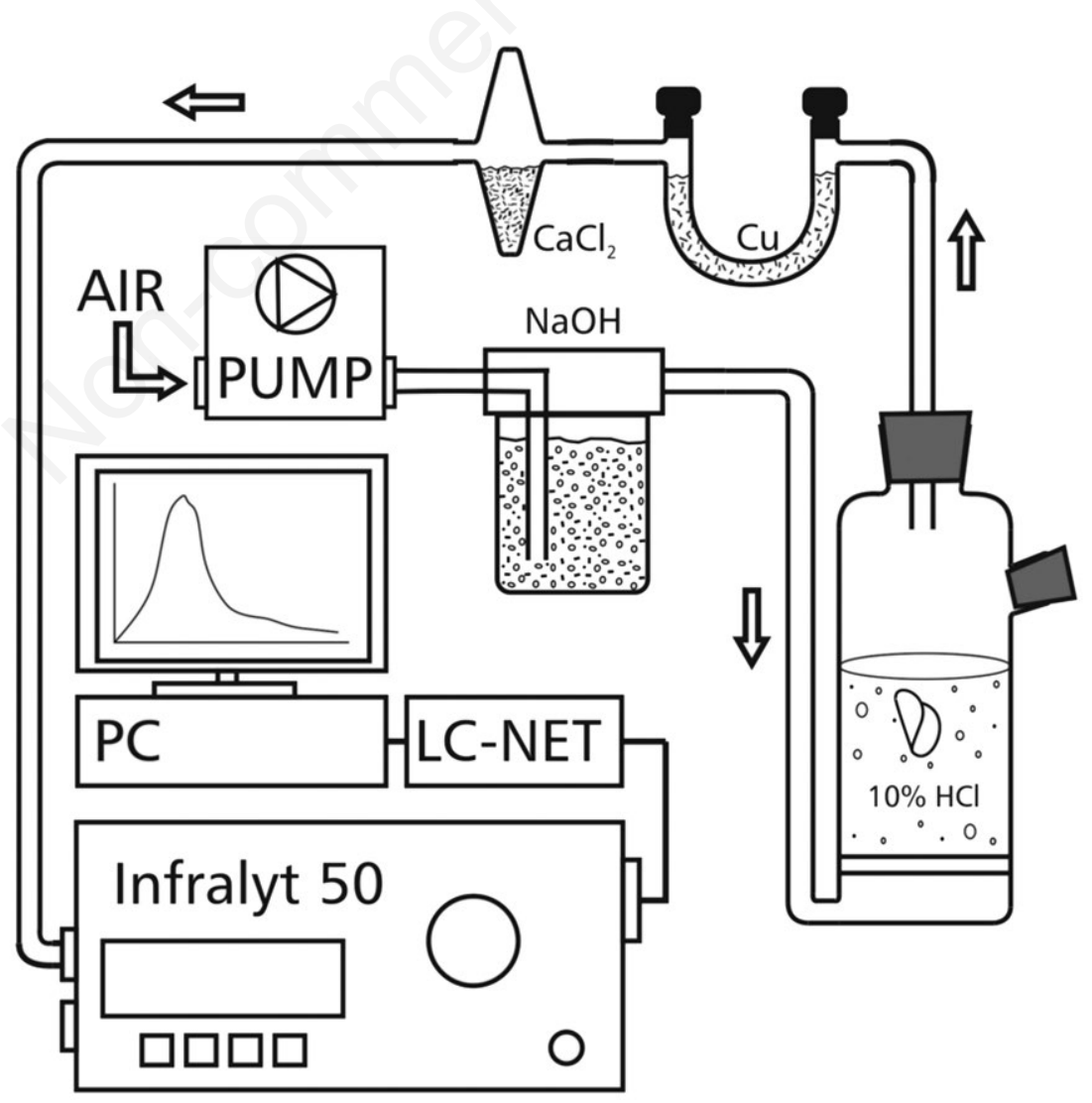

Fig. 1. Schematic representation of the carbonate infrared gas analysis measurement setup. 
calibration sample was measured to guarantee accurate results. The system was calibrated after every 60 measurements.

$$
c_{\mathrm{CaCO}_{3}}\left[\mathrm{mg} \mathrm{L}^{-1}\right]=c_{C}\left[\mathrm{mg} \mathrm{L}^{-1}\right] \times \frac{100.09 \mathrm{~g} \mathrm{~mol}^{-1}}{12.01 \mathrm{~g} \mathrm{~mol}^{-1}} \text { eq. } 1
$$

\section{Plankton analysis}

Plankton samples were stored in $100 \mathrm{~mL}$ brown glass bottles and preserved with Lugol's solution. Suspended shell concentrations in the water column were determined with an inverted microscope Leitz Labovert at 200-400× according to Utermöhl (1959). We counted single shells as one, and complete Phacotus housings as two shells. The cell density was derived by dividing the sum of the shells by two because a complete Phacotus housing consists of two shells. At least 300 individuals were counted per sample to ensure accurate determination of the shell numbers. Additionally, the shell diameter was determined by taking two perpendicular measurements. From each lake, 150 individuals (50 from three sampling events at different stages of population growth in June, July, and August 2016) were measured with the EOSMetrology software. To test for mean shell diameter differences between lakes and month of sampling, a twoway-analysis-of-variance (ANOVA) was conducted. In case of significance, Tukey's post-hoc tests were computed. Statistical analyses were carried out using the open source software R 3.2.2 (R Core Team, 2015).

\section{Focused ion beam processing}

Thin layer cross-sections of a Phacotus calcite shell were cut with a FEI (Hillsboro, Oregon, USA) Helios NanoLab G3 UC FIB. Prior to milling, samples were prepared on Si wafers and coated with $20 \mathrm{~nm}$ carbon using a Leica EM ACE600-Coater. To assure clean cut surfaces, the cutting area in the middle of each shell was sealed with a protective layer of Pt (Fig. 2 b-d) with a thickness of $1 \mu \mathrm{m}$, derived from ion induced deposition. The calcite shell was cut and polished using ion currents from $47 \mathrm{nA}$ to $2.5 \mathrm{nA}$, at an acceleration voltage (AV) of $30 \mathrm{kV}$. Scanning electron micrographs were obtained at $1.0 \mathrm{kV}$ $\mathrm{AV}$ with a viewing angle of $52^{\circ}$ to the ion beam. In total, 23 individuals were cut vertically in the middle and one shell horizontally, parallel to its flat side.

\section{Volume and mass determination}

A total number of 24 individuals from five lakes were FIB milled to obtain a site-specific view of the shell morphology and structure. On the shell cross-section images, profile lines along the outer margin of the shell were marked. Two profiles were drawn on each shell cross-section (Fig. 2d), resulting in 48 profiles of shell halves for cross-section image analysis. On these profiles, the following characteristic parameters (Fig. 2e) were measured (precision as relative error): minimal shell thickness $t_{\text {min }}(11.1 \%)$, rim width $t_{\text {Rim }}(2.0 \%)$, radius $r$ $(0.6 \%)$, diameter $\mathrm{d}$ and height $\mathrm{h}(1.4 \%)$. For each shell, profiles were converted to surface area and rotated $360^{\circ}$ to create a closed up 3D-body of rotation from which the volume $\left(\mu \mathrm{m}^{3}\right)$ was determined by using the CAD software Rhinoceros (McNeel, 2013).

For the estimation of total porosity $\Phi(\%)$, image analysis was conducted on 15 consecutive cross-section micrographs of two Phacotus individuals with the image analysis software FiJi ImageJ (Rasband, 2016). The total porosity was determined in terms of percentage of open pore area per unit shell area on the plane shell cut faces. To eliminate scale errors, we analysed with different sized analysis windows $(0.8 \times 0.8 \mu \mathrm{m}$ and $2.3 \times 0.7 \mu \mathrm{m})$ and repeated the measurement on at least five micrographs in series, of which each represented a $0.04 \mu \mathrm{m}$ deeper cut face of the investigated shell. Subsequently, the shell density $\rho\left(\mathrm{ng} \mu \mathrm{m}^{-3}\right)$ was calculated according to equation 2 with a density of $\rho_{0}=0.0027 \mathrm{ng} \mathrm{\mu m}^{-3}$ for pure calcite.

$\rho=\rho_{0}(1-\phi)$

eq. 2

The mass $\mathrm{m}$ of $\mathrm{CaCO}_{3}$ (ng) deposited in each individual Phacotus shell was calculated according to equation 3 by multiplying the volume of the 3D-body of rotation with $\rho$.

$\mathrm{m}=\mathrm{V} \cdot \rho$

eq. 3

\section{RESULTS}

\section{Calculation of shell mass}

Our measurements of 24 individuals from 5 lakes led to a mean volume of $334.1 \mu \mathrm{m}^{3}(\mathrm{SD}=70)$ for a complete Phacotus housing with a $13.9 \mu \mathrm{m}$ diameter (consisting of two shells). Our data showed that shells with the same diameter had a variation in volume up to a factor 1.8. The calculated mean shell mass for a complete specimen (comprising two valves) was $0.86 \mathrm{ng}(\mathrm{SD}=0.18)$. The mean shell mass ranged from $1.03(\mathrm{SD}=0.11)$ ng in lake Großer Ostersee to $0.66(\mathrm{SD}=0.10) \mathrm{ng}$ in lake Igelsbachsee (Tab. 2).

\section{Estimation of porosity}

Based on image analysis of the shell cut faces of the cross-section micrographs, highly massive calcite shells were identified (data not shown). We decided to calculate the material density according to equation 2 using total porosity derived from image analysis. The cut faces appeared even and showed only few cut pores. We 
analysed both a relatively porous and a highly massive appearing shell. The resulting estimated porosities were $2.9 \%$ for the porous and $2.2 \%$ for the massive shell. The smallest analysed pores had a pore-throat size of $50 \mathrm{~nm}$. Nevertheless, close-up scanning electron micrographs also showed mesopores with diameters smaller than 50 nm (Fig. 3a). These pores certainly contributed to an increased inner surface area but might not contribute to a significantly higher porosity. However, for further calculations, we assumed a total material porosity of $\phi=5 \%$ to take this fact into account. According to equation 2 , the shell density was $\rho=0.0026 \mathrm{ng} \mu \mathrm{m}^{-3}$.
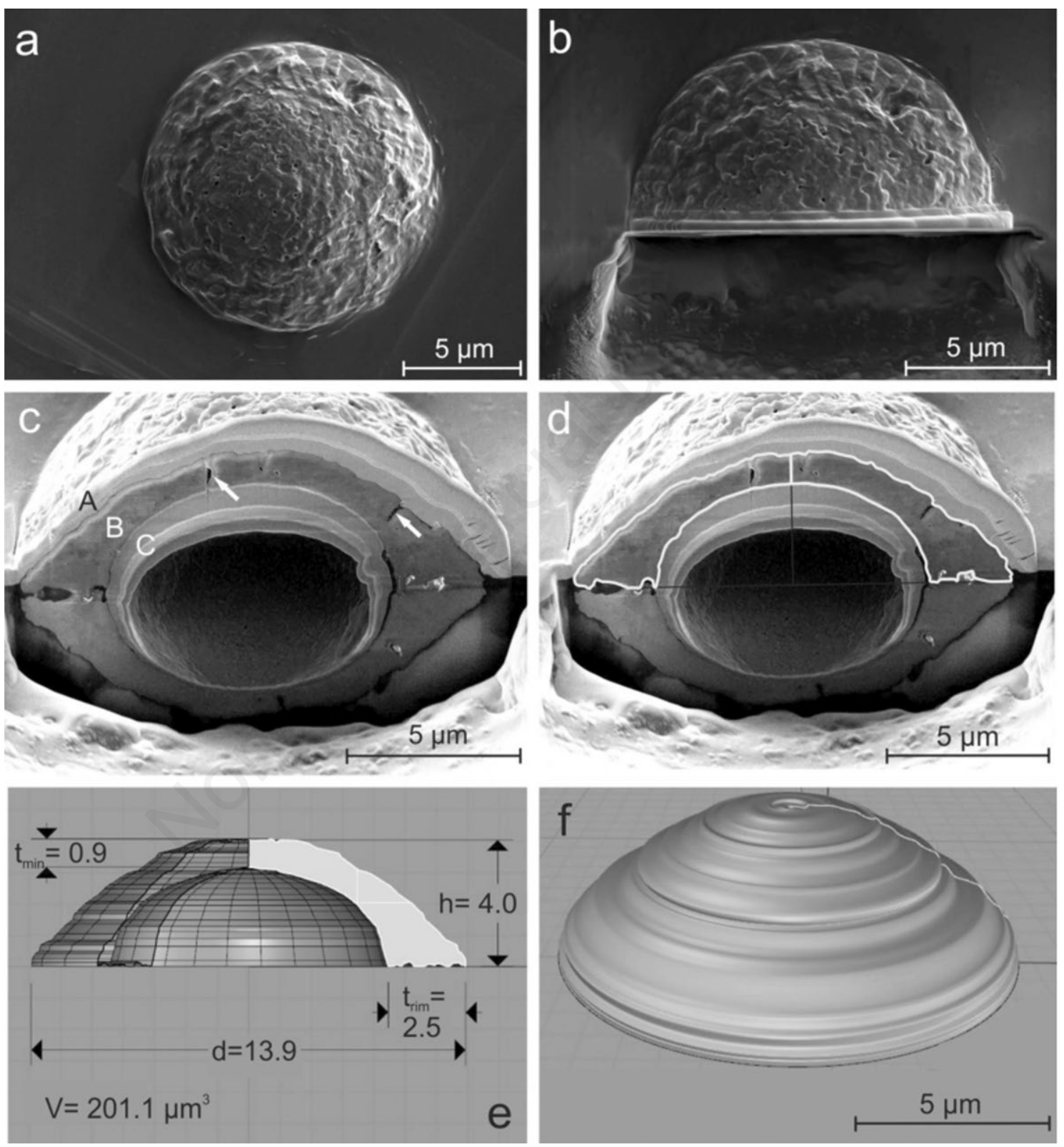

Fig. 2. Method for volume determination, scanning electron micrographs of a Phacotus lenticularis shell from lake Großer Ostersee, $4 \mathrm{~m}$ depth, June 2015: a) intact shell with flagella pore at the upper right and several small pores on its surface, plan view prior to FIB milling; b) shell, cut in the middle with narrow Pt-protection layer on cutting edge , plan view; c) imaging face of shell cross-section with two exposed pore canals (white arrows), light grey Pt coating (A) over dark grey shell material (B), layers of cutting debris, accumulated inside the shell during cutting process (C), side view; d) shell cross-section with both marked profile lines for creation of a 3D-body, side view; e) open 3D-body of rotation with profile of the cross-section and measuring bars, dimension are in $\mu \mathrm{m}$, side view perpendicular to profile; f) closed 3D-body for volume determination with Rhinoceros 3D software. 


\section{Variability of general dimensions on shell cross-sections}

The shell diameter (d) was significantly influenced by the lake's origin $(\mathrm{P}=0.007)$, but the month of sampling had no significant influence $(\mathrm{P}=0.190)$. The investigated shells in 2016 had a mean diameter of $13.8 \mu \mathrm{m}$ for lake Abtsdorfersee, $13.1 \mu \mathrm{m}$ for lake Altmühlsee, $12.7 \mu \mathrm{m}$ for lake Großer Ostersee, $14.0 \mu \mathrm{m}$ for lake Hopfensee, and $12.0 \mu \mathrm{m}$ for lake Igelsbachsee (Fig. 4). The biggest shell was found in lake Abtsdorfersee $(\mathrm{d}=21.9 \mu \mathrm{m})$, the smallest shell in lake Igelsbachsee $(\mathrm{d}=8.3 \mu \mathrm{m})$.

The shell size parameter height (h) varied significantly between the lakes. The shell thickness $\left(\mathrm{t}_{\min }\right)$ and rim width $\left(t_{\text {Rim }}\right)$ showed significant variation only for the shells from lake Großer Ostersee (Tab. 2). The $\mathrm{h} / \mathrm{d}$ ratios of the

Tab. 2. General dimensions, volumes and calculated masses of Phacotus shells.

\begin{tabular}{lccccc} 
& Gr. Ostersee & Abtsdorfersee & Igelsbachsee & Hopfensee & Altmühlsee \\
Mass* $(\mathrm{ng})$ & $0.52(0.06)$ & $0.43(0.09)$ & $0.33(0.05)$ & $0.40(0.06)$ & $0.48(0.05)$ \\
Volume $\left(\mu \mathrm{m}^{3}\right)$ & $201.7(32.6)$ & $167.0(36.9)$ & $128.4(21.4)$ & $155.4(22.8)$ & $186.7(21.5)$ \\
Diameter $(\mu \mathrm{m})$ & $13.6(0.9)$ & $14.0(1.2)$ & $12.5(0.5)$ & $15.0(1.2)$ & $15.0(0.4)$ \\
Rim width $(\mu \mathrm{m})$ & $2.4(0.4)$ & $2.1(0.4)$ & $1.8(0.2)$ & $1.6(0.3)$ & $2.0(0.3)$ \\
Thickness $(\mu \mathrm{m})$ & $1.0(0.1)$ & $0.7(0.2)$ & $0.8(0.2)$ & $0.7(0.1)$ & $0.8(0.1)$ \\
Height $(\mu \mathrm{m})$ & $4.2(0.3)$ & $4.5(0.4)$ & $4.2(0.1)$ & $4.8(0.6)$ & $4.8(0.2)$ \\
\hline
\end{tabular}

*Weight for a single shell half with 5\% porosity; 48 shell profiles of 24 individuals were measured. Samples were taken in June and August 2016.
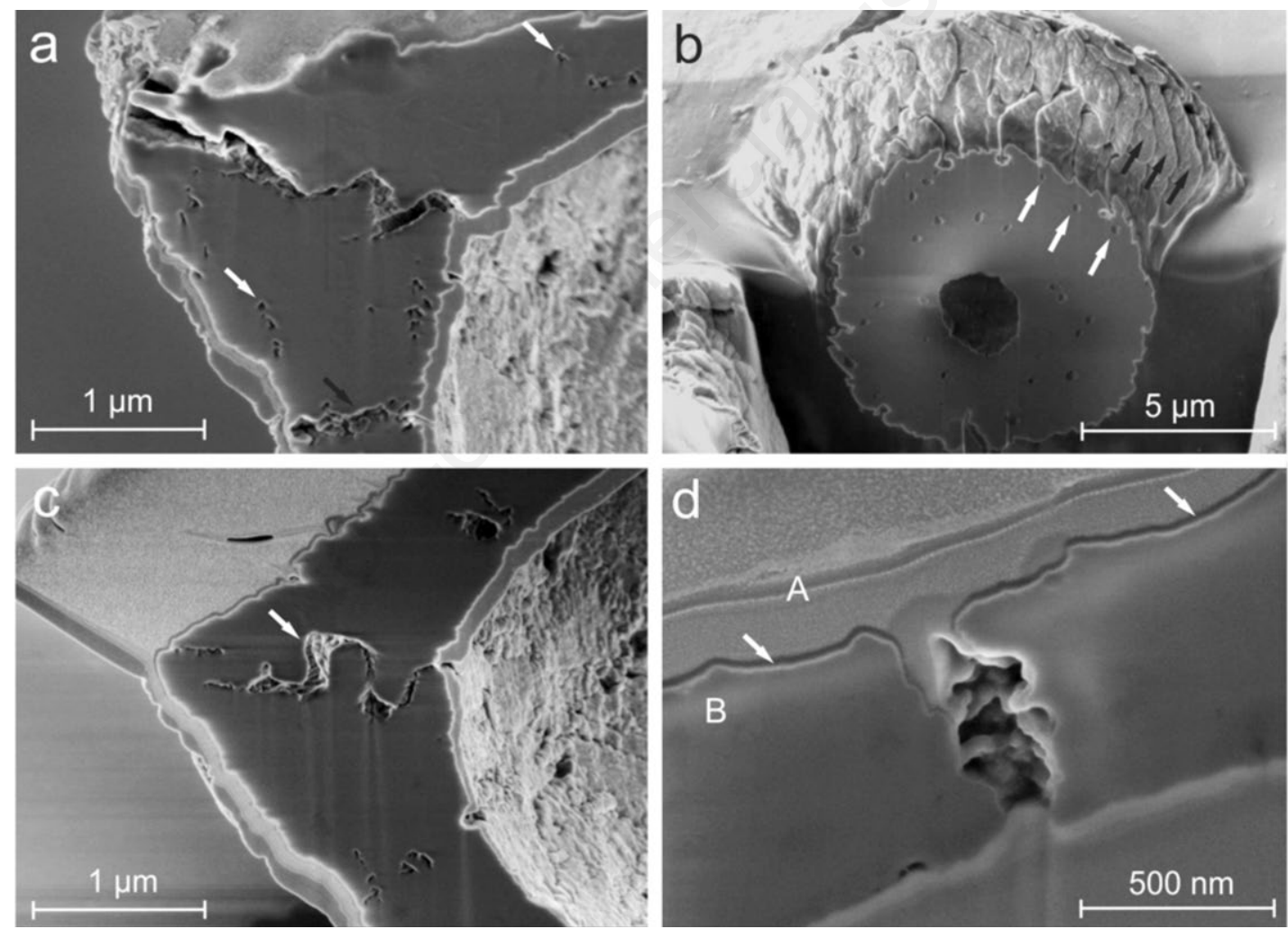

Fig. 3. Close-up scanning electron micrographs of internal pores and cavities on the shell cross-sections: a) contact zone at the shell margin, cut tabular rhombohedral calcite crystals show a step-like cut edge, there are micro pores (white arrows) and a pore-canal (black arrow) in the massive calcite shell; b) imaging face in upper shell zone, horizontally cut parallel to contact planes, tabular rhombohedral calcite crystals (black arrows) are visible on the outer most two rings at the shell margin, inner calcite seems to be very massive and interspersed with few, small pores (white arrows), side view; c) contact zone on the shell rim, calcite crystals are interlocked, the cavity between the two shells (white arrow) formed during imaging process, previously filled with an unknown substance volatile in vacuum under an electron beam; d) shell cross-section in the central zone, pore-canal that intersects the complete shell from inside to outside, its cavernous rim appeared during the imaging process and was also filled with the unknown substance, Pt-protection coating (A), dark $20 \mathrm{~nm}$ C-sputter-layer (white arrows), actual shell calcite (B). 
Phacotus shells from each lake remained constant $(0.32$; $\mathrm{SD}=0.02)$. The characteristic appearance of the shells from different lakes might be better reflected by the ratio of the shell thickness to its diameter. Shells from two lakes showed remarkable characteristics: the shells from lake Hopfensee had a filigree shell architecture with a low $\mathrm{t}_{\text {min }} / \mathrm{d}$ ratio of $0.045(\mathrm{SD}=0.010)$, whereas shells from lake Großer Ostersee showed a massive architecture with a high $\mathrm{t}_{\min } / \mathrm{d}$ ratio of $0.075(\mathrm{SD}=0.011)$. In contrast, the $\mathrm{t}_{\mathrm{Rim}} / \mathrm{d}$ ratio was not a good descriptive value because it was dominated by the variation in the shell diameter.

\section{Observations of the shell ultrastructure}

The analyses of calcite shell cross-sections from SEM images confirmed that the internal structure consisted of closely stacked tabular calcite crystals. They had approximate dimensions of $1.0 \times 1.6 \times 0.2 \mu \mathrm{m}$. Most of the interspaces were predominately cemented with superfine-grained calcite lacking a specific crystal structure. Some interspaces were unfilled and formed cylindrical elongated pores that did not penetrate the entire shell. Most pores were not interlinked and ceased before reaching the outer layer. In the inner most shell areas, small pores were pitched in a circular-spiral arrangement along the smaller lateral edge of the tabular crystals (Figs. $2 \mathrm{a}$ and $3 \mathrm{~b}$ ). The majority of pores that could be seen at the shell surface were from this type and had an average diameter of $0.11 \mu \mathrm{m}(\mathrm{SD}=0.03)$.
Another kind of pore, fewer and likely situated in the central shell area, intersected the whole shell (Figs. 2c and $3 \mathrm{a}, \mathrm{d})$. These pore canals had wider pore-throats of approximately $0.2 \mu \mathrm{m}$ and irregular pore walls. According to the behaviour during SEM imaging, these pores seemed to be coated or filled with a volatile organic substance that disappeared under the electron beam under vacuum conditions. The space in the contact zone between the two shells (rim interspace) was filled with the same substance and showed tabular crystals almost interlocked with each other (Fig. 3c).

\section{Phacotus induced calcite precipitation}

To quantify the autochthonous calcite precipitation in the epilimnion of lake Großer Ostersee, we measured the amount of total calcite in the upper $5 \mathrm{~m}$ of the water column. Remarkably high concentrations of total suspended carbonate of over $1.5 \mathrm{mg} \mathrm{L}^{-1}$ were reached from mid-July until mid-September, with a maximum of $3.2 \mathrm{mg} \mathrm{L}^{-1}$ (Fig. 5).

During the peak development of Phacotus lenticularis on $16^{\text {th }}$ June 2015 , the maximum cell density reached 477,800 ind. $\mathrm{L}^{-1}$ in $2 \mathrm{~m}$ depth. The average value for the epilimnion $(0-5 \mathrm{~m})$ was 153,327 ind. $\mathrm{L}^{-1}$. During this occasion, $21.5 \%$ of precipitated calcite was provided by Phacotus lenticularis. This peak was followed by a sudden decrease in cell numbers coinciding with rain- and wind-induced epilimnetic mixing and grazing by

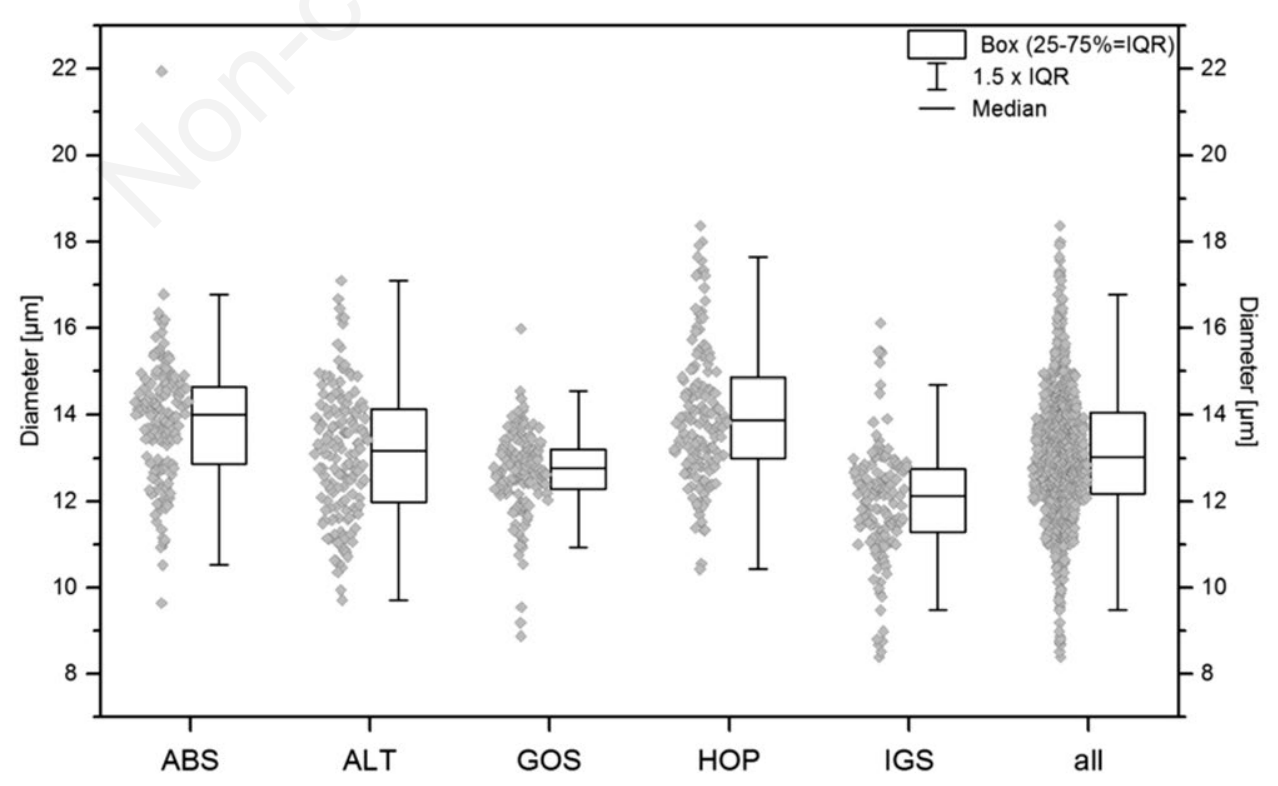

Fig. 4. Variation of Phacotus shell diameters measured during cell counting 2016: total n was 150 for each lake; 50 from June, July and August each. Data points as grey squares; summary as box including first to third quartile $(25-75 \%=$ interquartile range IQR), whiskers describe $1.5 \times \operatorname{IQR}(12.5-87.5 \%)$. The line represents the median. Abbreviations as indicated in methods section. 
zooplankton. Three additional Phacotus peaks occurred in early July, in late July, and in mid-September. The average amount of precipitated calcite provided by Phacotus lenticularis over the whole monitoring period was $6.0 \%$ in relation to total suspended calcite owing to the high total precipitated calcite concentrations in the epilimnion.

In the epilimnion of lake Großer Ostersee the average carbonate concentration per square metre of lake surface was $6.53 \mathrm{~g} \mathrm{CaCO}_{3} \mathrm{~m}^{-2}$ (as average over the whole investigation period from $7^{\text {th }}$ June to $3^{\text {rd }}$ November 2015 in $0-5 \mathrm{~m}$ water depth). At peak concentrations on $11^{\text {th }}$ August 2015, the values reached $16.1 \mathrm{~g} \mathrm{CaCO}_{3} \mathrm{~m}^{-2}$. The total contribution of Phacotus lenticularis $(6 \%)$ on the mean value was $0.38 \mathrm{~g} \mathrm{CaCO}_{3} \mathrm{~m}^{-2}(0-5 \mathrm{~m})$ and reached $0.80 \mathrm{~g} \mathrm{CaCO}_{3} \mathrm{~m}^{-2}$ during Phacotus peak concentrations $(21.5 \%)$ on $16^{\text {th }}$ June 2015 .

\section{DISCUSSION}

This study provides a novel methodological basis for a quantitative assessment of Phacotus precipitated carbonate in relation to the total carbonate precipitation in lakes. We examined the variations of the Phacotus shape and determined the resulting weight of its shells, which was the most relevant variable in this investigation. Our investigation revealed that the lake's origin significantly influenced the shell diameters and height. Accordingly, the shell volumes and masses varied strongly between lakes. It seems unlikely that dissolution was the reason for the variation in diameter or mass of the shells because neither the water chemistry (Tab. 1), nor the selective electron micrographs of the epilimnetic material (Figs. 2 and 3), showed evidence of dissolution of Phacotus shells or calcite crystals in any of the lakes. The shells were found to be highly massive with few pores of different types (i.e., porosity $<5 \%$ ). This resulted in a shell mass for Phacotus lenticularis which was 2.8fold higher than the current estimation of $0.3 \mathrm{ng} \mathrm{CaCO}_{3}$ per individual reported by Koschel et al. (1987).

There might be several reasons that explain why our size-adjusted mass estimation based on 24 individuals from 5 lakes show a higher and more realistic shell mass (0.86 ng $\left.\mathrm{CaCO}_{3}\right)$ compared to current estimates. First, differences in the methodological approaches need to be considered: in contrast to our study, Koschel et al. (1987) had the favourable and rare circumstance of lake water samples in which $100 \%$ of the suspended carbonate was derived from $P$. lenticularis cells. Thus, the amount of

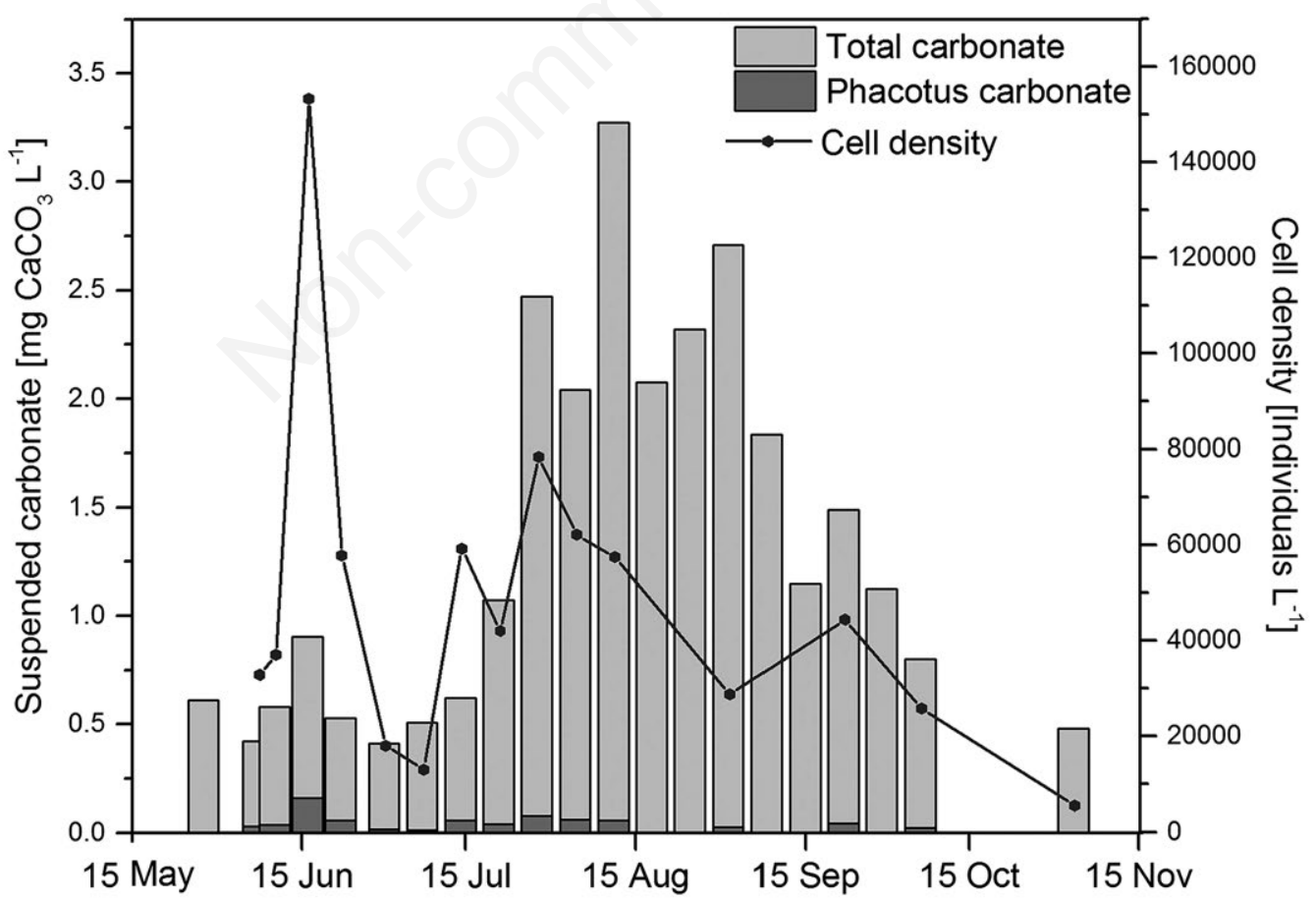

Fig. 5. Total particulate carbonate (light bars) and amount of precipitated calcite provided by Phacotus lenticularis (dark bars). Total carbonate values were measured by infrared gas-analysis whereas Phacotus carbonate values were calculated using an individual's mass of $1.03 \mathrm{ng}$ (two shells). Not all sampling dates have Phacotus cell density data (line). All shown data are integrated for 0-5 m of lake Großer Ostersee in 2015. 
carbonate from a certain volume of lake water (on a filter) could be measured conductometrically. The individual shell mass was then calculated through division with the microscopically determined cell concentration.

This approach might have resulted in an inferior shell mass value either because of common inaccuracies during microscopic cell counting or, owing to insufficient transfer of shells from the lake water onto the membrane filters. Homogenisation and division are difficult owing to fairly swift sedimentation of the Phacotus shells and can lead to depleted Phacotus shell concentrations in decanted water samples.

In our opinion, the methodology we used for volume determination can be considered less prone to errors. Using state-of-the-art FIB technology, the accuracy in imaging was high and scaling for the $3 \mathrm{D}$-software had an absolute precision of less than $0.06 \mu \mathrm{m}$ and the subsequent volume calculation had an extremely low mean error of $1.3 \times 10^{-5} \mu \mathrm{m}^{3}\left(\mathrm{SD}=1.2 \times 10^{-5}\right)$. However, our method for calculating the mass is not entirely unproblematic because the proportion of mesoporosity had to be estimated (in our case $2.4 \%$ additional to the measured macroporosity with an average of $2.6 \%$ ). This resulted in a presumed total porosity of approximately $5 \%$. Accordingly, our calculated shell density $(\rho=0.0026$ $\mathrm{ng} \mu \mathrm{m}^{-3}$ ), was only slightly lower than the of massive calcite. This value is in accordance with the density of biomineralised calcite of planktonic marine algae (dried coccolith powder) measured with a gas pyknometer (Hariskos et al., 2016) and seems plausible in regard to the very massive looking shell cross-sections on the closeup scanning electron micrographs (Fig. 3). In accordance with this, values from Koschel et al. (1987) do not seem to be realistic: applying their reported shell density of $\rho_{s}=0.0006 \mathrm{ng} \mathrm{\mu m}^{-3}$ to equation 2 , the resulting porosity $\Phi$ of $77.8 \%$ seems exorbitantly high.

Secondly, in the different study lakes the natural variation of the general Phacotus size also caused large differences in the mean shell masses and could be an explanation for the difference in shell mass results. In previous publications, these natural variations were not subject to special interest. However, they are highly relevant if the quantitative Phacotus contribution to the total carbonate precipitation in lakes is being determined. Our measurements on individual cells from five lakes of different trophic states and mixis showed that Phacotus lenticularis had a great variability in size and morphology. Also Koschel and Raidt (1988) identified a strong variation in shell diameter in all of their investigated water bodies. Our investigated shells with diameters in the range of $14.0 \pm 2.4 \mu \mathrm{m}$ are typical. According to Koschel and Raidt (1988) shell diameters over $14 \mu \mathrm{m}$ can be considered as large and Giering (1990) states that shells with smaller diameters $(7-12 \mu \mathrm{m})$ "may indicate daughter cells, in which shell development is incomplete".

Our analyses of the internal shell ultrastructure revealed that the small pores from the crystal interspaces were pitched in a circular-spiral arrangement along the smaller lateral edge of the tabular crystals. This means that we can confirm the oval-circular arrangement of the crystals in the shell centre (Fig. 3b) and the observations of Kampner (1950) as well as those by Koschel and Raid (1988). They described the rotational symmetry of the crystals at the marginal shell rim and dissymmetrical orientation in the centre of the cell, similar to a "skiodromen model". Predominantly located in the central shell area, we found a second type of pore, the pore canals. In contrast to the descriptions of Giering (1990), we could not confirm that all of the pores on the inner shell surface were "openings of the pore canals penetrating the lorica". Actually, only a few of them intersected the whole shell from the inside to the outside (Figs. 2c and 3a, d). These pore canals were wider than the pores in the crystal interspaces and showed irregular pore walls.

Furthermore, we can report that shells of vegetative cells do actually touch each other in the contact zone (Fig. 3a) and are sometimes even almost interlocked (Fig. 3c). The rim interspace seemed to be filled with a volatile substance, which under an electron beam under vacuum conditions slowly disappears. This substance might represent the mucilaginous sheath (Hepperle and Krienitz, 1996), previously called "gelatinous mother cell wall" (Giering et al., 1990). We observed that the pore channels seem to be coated or filled with this same volatile organic substance. In our opinion, it seems more probable that the exchange of substances during the motile cell state of Phacotus lenticularis is carried out through the pore canals rather than through the rim interspace in the contact zone, as suggested by Kamptner (1950).

Finally, we can report a remarkable contribution of Phacotus lenticularis to the total suspended calcite precipitation in lake Großer Ostersee of $21.5 \%$ at peak cell densities. Kienitz et al. (1993) reported the mean percentages of Phacotus calcite of the total suspended epilimnetic calcite in several hard-water lakes of northern Germany ranged from 5\%-20\% and reached $54 \%$ in exceptional circumstances. Fluctuating Phacotus populations and irregularly oscillating total calcite precipitation rates were mentioned as reasons for the wide range of variation. Furthermore, the trophic state of the lake has to be considered as an important influencing factor. Significant Phacotus calcite percentages are expected predominantly in eutrophic and highly eutrophic lakes (Schlegel et al., 1998).

The total contribution of Phacotus lenticularis on the epilimnic mean carbonate concentration per square meter reached up to $21.5 \%$ during peak concentrations and on 
average $6 \%$ over the whole investigation period ( $7^{\text {th }}$ June - $3^{\text {rd }}$ November 2015). Taking into account that sedimentation is only responsible for about $20 \%$ of total current C-turnover from inland waters (Tranvik et al., 2009), and that at least half of the $C$ is precipitated in the form of organic carbon compounds (Noges et al., 2016), carbonate precipitation by Phacotus lenticularis represents a small but notable part of C-turnover in lakes. In hard-water lakes, it should certainly be considered in the assessment of lake carbon cycling.

\section{CONCLUSIONS}

An accurate quantification of the carbonate sequestration of Phacotus lenticularis in lakes requires precise estimation of its shell sizes, masses, and the variations of both variables in relation to spatio-temporal variability. The mean diameter from times during highest cell densities should be used as the basis for all calcite mass calculations. During these events, Phacotus lenticularis actually provides relevant amounts of epilimnetic suspended calcite. Further investigation is necessary with respect to persistence, and actual amount of Phacotus carbonate stored in recent lacustrine sediments and whether shells tend to be re-dissolved on their way from the epilimnion to the lake bottom.

\section{ACKNOWLEDGMENTS}

Funding has been provided by the Bavarian State Ministry of the Environment, Project Nr. TLK 10U-6627. We are grateful to Prof. Peter Jacob for providing access to the FIB device and for his guidance, to Prof. Rainer Koschel for valuable advice and helpful comments on earlier versions of the manuscript and to Prof. Tanja Gschlöß1 for her continuous support of this project. We also thank Simone Rudolph and Lukas Heinrich for help in the field, in the laboratory and with the microscopic analysis.

\section{REFERENCES}

Cole JJ, Prairie YT, Caraco NF, McDowell WH, Tranvik LJ, Striegl RG, Duarte CM, Kortelainen P, Downing JA, Middelburg JJ, Melack J, 2007. Plumbing the global carbon cycle: Integrating inland waters into the terrestrial carbon budget. Ecosystems 10:172-185.

Giering B, Krienitz L, Casper SJ, Peschke T, Raidt H, 1990. LM and SEM observations on the asexual reproduction and lorica formation of Phacotus lendneri Chodat (Chlamydophyceae, Phacotaceae). Arch. Protistenkd. 138:75-88.

Gruenert U, Raeder U, 2014. Growth responses of the calcite- loricated freshwater phytoflagellate Phacotus lenticularis (Chlorophyta) to the $\mathrm{CaCO}_{3}$ saturation state and meteorological changes. J. Plankton Res. 36:630-640.

Hariskos I, Chairopoulou MA, Posten C, Teipel U, Vučak M, 2016. Characterisation of biogenic calcite particles from microalgae-coccoliths as a potential raw material for industrial application. Ecol. Eng. Environ. Prot. 7:36-41.

Hepperle D, Krienitz L, 1996. The extracellular calcification of zoospores of Phacotus lenticularis (Chlorophyta, Chlamydomonadales). Eur. J. Phycol. 31:11-21.

Kamptner E, 1950. [Über den Aufbau des Kalkgehäuses von Phacotus Lendneri CHOD.].[Article in German]. Österr. Bot. Z. 97: 391-402.

Koschel R, Proft G, Raidt H, 1987. [PhacotusMassenentwicklungen - eine Quelle des autochthonen Kalkeintrages in Seen].[Article in German]. Limnologica 18:457-459.

Koschel R, Raidt H, 1988. [Morphologische Merkmale der Phacotus-Hüllen in Hartwasserseen der Mecklenburger Seenplatte].[Article in German]. Limnologica 19:13-25.

Krienitz L, Koschel R, Giering B, Casper SJ, Hepperle D, 1993. Phenomenology of organismic calcite precipitation by Phacotus in hardwater lakes and ponds of northeastern Germany. Verh. Int. Verein. Limnol. 25:170-174.

McNeel R, 2013. Rhinoceros: CAD software, ver. 5.1.30129.1756. Robert McNeel \& Associates, Barcelona.

Müller G, Oti M, 1981. The occurrence of calcified planktonic green algae in freshwater carbonates. Sedimentology 28:897-902.

Noges P, Cremona F, Laas A, Martma T, Room E-I, Toming K, Viik M, Vilbaste S, Noges T, 2016. Role of a productive lake in carbon sequestration within a calcareous catchment. Sci. Total Environ. 550:225-230.

Pocratsky LA, 1982. Nutritional, chemical and ultrastructural characterization of the lorica and extracellular mucilage of Phacotus lenticularis (Phacotaceae, Volvocales). PhD Thesis, University Tennessee.

Proft G, 1983. [Automatische Bestimmung von Kohlendioxid und Carbonat in Wasser nach dem flow-stream-Prinzip]. [Article in German]. Acta Hydroch. Hydrob. 11:235-239.

Proft G, 1984. [Die pelagische Calcitfällung und der Carbonatgehalt von Sedimenten pleistozäner Seen]. [Article in German]. Acta Hydroch. Hydrob. 12:321-326.

R Core Team, 2015. R: A Language and Environment for Statistical Computing, ver. 3.2.2. R Foundation for Statistical Computing, Vienna.

Rasband WS, 2016. ImageJ: public domain Java image processing program, ver. v1.51h. National Institutes of Health, Bethesda.

Schlegel I, Koschel R, Krienitz L, 1998. On the occurrence of Phacotus lenticularis (Chlorophyta) in lakes of different trophic state. Hydrobiologia 369-370:353-361.

Schlegel I, Krienitz L, Hepperle D, 2000. Variability of calcification of Phacotus lenticularis (Chlorophyta, Chlamydomonadales) in nature and culture. Phycologia 39:318-322.

Siemińska J, 1952. The plankton of the artificial lake at the Roznow dam. Mem. Acad. Pol. Sci. B 18:1-109.

Sladecek V, Cyrus Z, Borovickova A, 1958. Hydrobiological investigations of a treatment of beet sugar factory's wastes 
in an experimental lagoon. Sbornik vus. skolu chem. techn. paliv a vodu: 121-150.

Steinberg C, Klee R, 1983. [Röntgenmikroanalyse der Schale einer einzelligen Grünalge: Chemismus einer Phacotus lendneri-Schale].[Article in German]. Mikrokosmos 72: 170-173.

Tranvik LJ, Downing JA, Cotner JB, Loiselle SA, Striegl RG, Ballatore TJ, Dillon P, Finlay K, Fortino K, Knoll LB, Kortelainen PL, Kutser T, Larsen S, Laurion I, Leech DM,
McCallister SL, McKnight DM, Melack JM, Overholt E, Porter JA, Prairie Y, Renwick WH, Roland F, Sherman BS, Schindler DW, Sobek S, Tremblay A, Vanni MJ, Verschoor AM, Wachenfeldt E von, Weyhenmeyer GA, 2009. Lakes and reservoirs as regulators of carbon cycling and climate. Limnol. Oceanogr. 54:2298-2314.

Utermöhl H, 1958. [Zur Vervollkommnung der quantitativen Phytoplankton-Methodik]. [Book in German]. E. Schweizerbart, Stuttgart: $38 \mathrm{pp}$. 